\title{
Tüketicilerin Restoran Seçim Ölçütleri Üzerine Bibliyografik Bir Değerlendirme
}

\author{
A Bibliograhic Assessment of Consumers' Restaurant Selection Criteria
}

\section{Şeyma Nur ÜZÜMa}

a Yüksek Lisans Öğrencisi, Çanakkale Onsekiz Mart Üniversitesi, Gastronomi ve Mutfak Sanatları Anabilim Dalı, Çanakkale, Türkiye.

b Dr. Öğr. Üyesi, Çanakkale Onsekiz Mart Üniversitesi, Ayvacık Meslek Yüksekokulu, Otel, Lokanta ve İkram Hizmetleri Bölümü, Çanakkale, Türkiye.

\section{Özet}

İnsanın en temel ihtiyaçlarından biri beslenme ihtiyacıdır. Dolayısıyla, beslenme olmadan insanların hayatını sürdürebilmesi mümkün değildir. Ayrıca, günümüzde çeşitli sebeplerden dolayı insanlar geçmişe oranla daha fazla dışarıda yemek yemektedirler. Beslenme ihtiyacına ek olarak, insanlar sosyalleşme, rahatlama, hizmet satın alma vb. nedenlerle de dışarıda yemek yemeyi tercih etmektedirler. Tüm sebeplerden dolayı yiyecek ve içecek sektörü her geçen gün hızla büyümektedir. Artan bu rekabet ortamında restoran işletmelerinin ayakta kalabilmesini sağlayacak unsurlardan biri tüketicilerin restoranları tercih etme sebeplerini bilmektir. Tüketicilerin restoran tercihlerine birçok faktör sebep olduğu gibi restoranın mimari yapısı da sebep olmaktadır. Restoran işletmeleri bu sebepleri bildiği taktirde, buna göre düzenlemeler, planlar yapabilir. İlgili literatür incelendiğinde, yurtiçinde ve yurtdışında konu ile ilgili birçok çalışma bulunmaktadır. Fakat bu çalışmaların bazıları restoran seçim ölçütleri yönünden ortak noktada birleştiği görülse de çoğunluğunda tüketicilerin restoran seçim ölçütlerinin farklı olduğu sonucu çıkarılmaktadır. Bu noktadan hareketle, bu çalışmanın amacı tüketicilerin restoran seçim ölçütleri üzerine yapılan çalışmalarda ortaya konan sebepleri bir çalışma altında incelemektir. Bu sayede, farklı çalışmalarda ortaya konan farklı ve benzer ölçütler kategorize edilebilecektir. İncelenen çalışmalara göre tüketicilerin restoran seçim ölçütleri; restoranın atmosferi, restoran imajı, yiyeceklerin kalitesi, hizmet kalitesi, restoranın fiziksel yapısı, parasal değer, otopark imkânı, kolaylıklar, personel kalitesi, hijyen, yiyeceklerin lezzeti, çocukların oyun oynayabilecekleri alan olması ve menü kalitesi gibi unsurlar şeklindedir. Çalışmanın sonucuna göre, müşterilerin restoranlara yalnızca karın doyurabilecekleri bir mekân olarak bakmamakta ve birçok faktörden etkilendiği görülmektedir. Dolayısıyla, rakipleri arasından öne çıkmak ve müşteriler tarafından tercih edilmek isteyen restoranların bu özelliklere sahip olması gerekmektedir. Yöneticilerin, tüketicilerin etkilendiği faktörleri bilmesi ve hizmet planlamasına dahil etmesi, müşterilerin beklentilerini karşılayabilmesi ve işletmenin devamlılı̆̆ı için önem arz etmektedir.

Anahtar Kelimeler: Restoran Seçim Ölçütleri, Tüketici, Bibliyografya.

\begin{abstract}
One of the most basic human needs is the need for nutrition and it is not possible to survive without nutrition. In addition, nowadays, for various reasons, people eat out more than in the past. In addition to the nutritional need, people socialize, relax, purchase services, etc. For reasons, they prefer to eat out. For all reasons, the food and beverage industry is growing rapidly every day. In this increasingly competitive environment, one of the factors that will enable restaurant businesses to survive is to know the reasons why consumers prefer restaurants. The architectural structure of the restaurant is also a factor that affects the preferences of consumers as well as the many other factors. If restaurant businesses know these reasons, they can make arrangements and plans accordingly. When the relevant literature is examined, there are many studies on the subject at home and abroad. However, although some of these studies seem to have a common point in terms of restaurant selection criteria, it is concluded that consumers' restaurant selection criteria are different in most of them. From this point of view, the aim of this study is to examine the reasons revealed in the studies on the restaurant selection criteria of the consumers under a study. In this way, different and similar criteria set forth in different studies can be categorized. According to the reviewed studies, consumers' restaurant selection criterias listed as; atmosphere of the restaurant, image of the restaurant, quality of the foods, quality of the service, physical structure of the restaurant, monetary value, parking facilities, the amenities provided, quality of the personnel, hygiene, taste of the foods, play areas for children, quality of the menu. According to the result of the study customers do not look at restaurants as just a place where they can fill their stomachs, they are also affected by alot of factors. Hence, the restaurants that wants to stand out among competitors and preferred by customers must have these features. It is important for managers to know the factors that affect consumers and include them in service planning, so that they can meet the expectations of customers and ensure the continuity of the business.
\end{abstract}

Keywords: Restaurant Selection Criteria, Consumer, Bibliography.
Makale Bilgisi

Geliş Tarihi

12.08.2021

Kabul Tarihi

Sayı Editörüi

Sağbetullah MERİÇ

Sorumlu Yazar

Şeyma Nur Üzüm suzum978@gmail.com @e

\section{Önerilen Atıf:}

Üzüm, Ş. N. ve Temeloğlu, E. (2021). Tüketicilerin Restoran Seçim Ölçütleri Üzerine Bibliyografik Bir Değerlendirme. Journal of Academic Tourism Studies, 2(2): 26-41. 


\section{GİRİ̧̧}

İnsanların yeme-içme ihtiyaçlarını karşılamak için hizmet sunan restoranlar (Kılınç, 2011: 34) küreselleşmenin giderek hız kazanması ve diğer çeşitli sebeplerden dolayı sürekli olarak artış göstermektedir. Böylelikle sektörde işletmeler arasında rekabet ortamı oluşmaktadır. Artan rekabet nedeniyle restoranların ürettikleri mal ve hizmetler bakımından sektördeki diğer restoranlardan farklılaşması gerekmektedir. Bu sayede rakiplerinden farklılaşan ve öne çıkan işletmelerin kar oranı da artmaktadır (Taşdağıtıcı ve Güçer, 2016: 1121). Restoranlar, sunduğu mutfak, servis boyutu, menüsü ve düzenlemeleri bakımından farklılaşmaktadır (Doğan, Şanlıer ve Tuncer, 2010: 242). Restoranın türü, müşterilerin satın alma öncesi tutumları ile satın alma sonrası değerlendirmeleri üzerinde önemli bir etkiye sahip olabilmektedir (Kim ve Chung, 2011: 2). Dolayisiyla, benzer amaçlara yönelik çok fazla restoran işletmesinin faaliyet gösterdiği bir ortamda rekabet avantaj1 sağlamak önemlidir (Fidan, Teneva, Stankov ve Dimitrova, 2018).

Çağdaş pazarlama anlayışına göre, pazarlama stratejilerinin temelinde tüketici bulunmaktadır (Eroğlu, 2012: 4). Restoran sayısında yaşanan artış, tüketicilerin pek çok alternatifle karşı karşıya gelmesine neden olmaktadır. Tüketicilerin, alternatifler içerisinde tercih yaparken önemli gördüğü ve tercihlerini etkileme durumu olan farklı faktörler bulunmaktadır (Akgündüz, Akdağ ve Metin, 2019: 2). Bu faktörlere bakıldığında, işletmede sunulan yiyeceğin kalitesi, restoranın tarzı ve atmosferinin restoran seçiminde belirleyici bir rol oynadığı görülmektedir (Auty, 1992: 324). Farklı özelliklere sahip müşterilerin restoran seçiminde farklı kriterler kullanma eğilimde olduklarını bilmek gerekir. Bu kriterler, müşterilerin nerede yemek yiyeceklerine karar verirken kullandıkları en önemli niteliklerdir (Kim ve Chung, 2011:1-2). Tüketicilerin tercihlerini etkileyen faktörlerin aynı zamanda memnuniyet oluşturmasıla sadakati etkilediği görülmüştür (Hyun, 2010: 263). Restoran yöneticileri, oluşan bu rekabet ortamında ayakta kalabilmek, müşterilerin ihtiyaçlarını karşılayabilmek ve rakiplerinden önde olabilmek için tüketicilerin isteklerine dikkat etmek durumundadır (Albayrak, 2014: 190). Bu doğrultuda, müşterilerin ihtiyaçlarının karşılanması ve restoran seçiminde etkili olunabilmesi için yöneticilerin, müşterilerin restoran seçiminde etkili olan faktörleri tanıması önem arz etmektedir (Aşık, 2019: 151). Dolayısıyla bu çalışmanın amacı, tüketicilerin restoran seçim ölçütlerinin belirlendiği çalışmaları bir araya toplamaktır. Bu amaçla, literatürdeki çalışmalarda ortaya çıkan, müşterilerin restoran seçmelerinde etkili olan benzer ve farklı faktörler belirtilmiş olacaktır.

\section{TÜKETİCI KARAR VERME SÜRECİ}

Tüketiciler sürekli olarak ürün ve hizmetlerin seçilmesi, satın alınması ve kullanılması ile ilgili kararlar almaktadır. Ancak tüketiciler, çok sayıda alternatifle karşı karşıya kaldıkları için bu kararları vermekte zorlanmaktadırlar. Bu alternatiflerin her biri birkaç özelliğe sahip olmakta ve tüketiciler, alternatifler arasından birini tercih etmek durumundadır (Bettman, Johnson ve Payne, 1991: 50-51). Tüketici karar verme süreci, Dewey (1910) tarafından öncülük edilen beş aşamalı bir karar sürecidir. Dewey'in (1910) ortaya attığı bu süreç; problem tanıma, araştırma, alternatiflerin değerlendirilmesi, seçim ve sonuç şeklindedir. Tüketici karar verme süreci, tüketicilerin bir ihtiyacı olduğunu fark ettiğinde başlamaktadır (Clemes, Gan ve Sriwongrat, 2013: 416). Daha sonra, bilgi arama ve dikkate alınan alternatifler kümesi oluşturma şeklinde devam etmektedir. Oluşturulan küme içerisinde alternatifler değerlendirilmekte ve seçim yapılmaktadır. Seçim aşamasındaki satın alma eyleminin gerçekleştirilmesi ve tüketim deneyiminin değerlendirilmesiyle süreç son bulmaktadır (Lawson, 1997: 428). Tüketicilerin karar verme sürecine girdikleri bir durum da dişarıda yemek yemeye karar vermektir.

Günümüzde bireylerin gelirinde yükselme olması, kadınların iş hayatına girmesi, yoğun çalışma saatleri, zamandan kazanma, sosyalleşme, kolaylık, evde yemek yapmaktan kaçınma ve yenilik gibi unsurlar, bireylerin dışarıda yemek yemelerinin artmasını sağlamıştır (Cevizkaya, 2015: 42). Tüketiciler, aralarında seçim yapabilecekleri çok çeşitli ürün ve hizmet sunan binlerce restoran seçeneğine sahiptir (Akbar ve Alaudeen, 2012: 137). Dolayısıyla dışarıda yemek yemeye karar veren 
bireyler, nerede ve ne yiyeceğine de karar verme durumunda kalmaktadır. Tüketiciler, yemek yeri seçimine karar verme aşamasında birçok faktöre önem vermektedir. Karar verme esnasında, restoranların sunduğu yemeğin kalitesine, ürün çeşitliliğine, fiyatına, işletmenin atmosferine ve imajına dikkat edecektir (Özdemir, 2010: 222-223). Müşterilerin önem verdiği bu faktörler, çeşitli nedenlerle farklılık gösterebilmekte ve oluşan farklılıklar ile tüketiciler, tercihlerine göre restoran seçmeye yönelmektedir (Choi ve Zhao, 2010: 238). Yapılan bir araştırmada, farklı yaşa, cinsiyete ve eğitim seviyelerine sahip tüketicilerin her birinin farklı faktörlere önem verdiği görülmüştür (Yüksekbilgili, 2014: 6358). Tüketicilerin bir restoranı diğerine tercih etme kararlarını etkileyen temel ve çevresel faktörleri anlamak, tüketiciler hakkında daha fazla bilgi sahibi olunması ve restoranın karlılığını arttırması bakımından önemli olmuştur (Alonso, O'neill, Liu ve O'shea, 2013: 550). Dolayısıyla bir restoran işletmesinin, tüketicilerin dışarıda yemek yerken neye ihtiyaç duyduğunu ve ne istediğini bilmesi gerekmektedir (Choi ve Zhao, 2010: 238).

\section{LITERATÜR TARAMASI}

Heung (2002) tarafından Hong Kong'da yapılan çalışmada, tüketicilerin Amerikan temalı restoranları tercih etmelerinde etkili olan faktörlerin belirlenmesi amaçlanmıştır. Belirlenen altı restoran üzerinde yapılan çalışma için katılımcılar ile yüz yüze görüşülmüş ve toplamda 180 müşteriden veri elde edilmiştir. Çalışmanın sonucunda, tüketicilerin restoran seçimini etkileyen beş önemli boyut ortaya çıkmıştır. Bu boyutların; yiyecek, servis, fiyat, atmosfer ve çekicilik olduğu görülmüştür.

Cullen (2005) tarafından Dublin'de yapılan çalışmada, tüketicilerin restoran seçim sürecinde etkili olan faktörlerin incelenmesi amaçlanmıştır. Çalışmada karma araştırma yöntemi benimsenmiştir. Çalışmanın sonucunda, tüketicilerin restoran seçimlerine neden olan faktörlerin öncelikle, 'yiyecek kalitesi, yiyecek türü, konum, temizlik, atmosfer, imaj ve hizmet kalitesi' olduğu görülmüştür.

Tayfun ve Tokmak (2007) tarafından Ankara'da yapılan araştırmada, Türk usulü fastfood restoran tercih nedenlerinin belirlenmesi amaçlanmıştır. Bu kapsamda, 212 restoran müşterisine anket uygulanmıştır. Çalışmanın sonucunda, 'menülerin doyurucu olması, damak tadına uygun menü sunumu, hizmetin zamanında ve hızlı olması, ulaşım kolaylığı, restoranın işyerine ve eve yakın olması' belirlenen kriterler olmuştur. Ayrıca, bireylerin demografik özelliklerine göre restoran seçim kriterlerinde farklılık olduğu gözlenmiştir.

Batra (2008) tarafından Bangkok'ta yapılan çalışmada, turistlerin etnik restoranda yemek yeme motivasyonları, bu restoranlarda yemek yemelerine etki eden faktörler ve Batılı ile Asyalı turistlerin dışarıda yemek yeme algılarındaki farklılıkların belirlenmesi amaçlanmıştır. Belirlenen 8 etnik restoran üzerinden 200 Asyalı ve 200 Batılı olacak şekilde toplam 400 kişiye anket uygulanmıştır. Çalışmanın sonucunda, tüketicilerin motivasyon faktörleri içerisinde en önemlisinin 'keşif' olduğu ve turistler için reklamın önemli bir bilgi kaynağı olduğu gözlenmiştir. Etnik restoranları tercih etmedeki faktörlere bakıldığında ise, Asyalı katılımcılar için 'sunulan yemeğin tadı ve otantik pişirme'; Batılı katılımcıların için 'etnik yemeklerin görünümü, sağlıklı yiyecek ve menü' önemli olmuştur. Bunlarla birlikte, dekor ve atmosferi yansıtan kültürel ipuçlar, kültür aşinalığı ve evde hazırlanması zor olan yemekler olması müşterilerin tercihlerini etkilemiştir.

Njite, Dunn ve Kim (2008) tarafından yapılan çalışmada, lüks restoranların tercihinde etkili olan faktörlerin belirlenmesi amaçlanmıştır. Bu doğrultuda, 10 tüketici ile derinlemesine görüşmeler gerçekleştirilmiştir. Çalışmanın sonucunda, 'müşteri ilişkileri'nin en önemli kriter olduğu görülmüştür. Fiyat, atmosfer, çalışanın yetkinliği ve rahatlık diğer restoran seçim kriterlerini oluşturmuştur.

Choi ve Zhao (2010) tarafından Güney Florida'da yapılan çalışmanın amacı, tüketicilerin restoran seçmelerinde etkili olan kriterleri belirlemektir. Bu kapsamda, restoran müşterileri üzerinde uygulanan anketlerden 307 kullanılabilir anket ede edilmiştir. Çalışmanın sonucunda, tüketicilerin restoran seçimlerinde etkili olan, 'restoranın ortamı, sağlık sorunu ve ekonomik değer' 
olarak 3 faktör oluşmuştur. Bu doğrultuda, atmosfer, hizmet, sağlıklı yiyecekler, ürün fiyatı ve porsiyon boyutu önemli görülmüştür.

Kim, Raab ve Bergman (2010) tarafından yapılan çalışmada, yaşlı turistlerin restoran seçim kriterlerinin belirlenmesi amaçlanmaktadır. Bu amaç doğrultusunda, Las Vegas'ta bulunan 50 yaş ve üstü bireylere anket uygulanmıştır. Lüks restoranlar için restoran seçim kriterleri 'yiyecek ve içeceğin lezzeti, yiyecek ve içeceğin kalitesi ve hizmet kolaylığı' olmuştur. Açık büfe restoranlar için seçim kriterlerinin 'menü çeşitliliği, yiyecek ve içeceğin lezzeti, otopark ile yiyecek ve içeceğin kalitesi' olduğu görülmüştür. Gündelik restoranlara bakıldığında ise, 'yiyecek ve içeceğin lezzeti, yiyecek ve içeceğin kalitesi ile hizmet kolaylığı' olduğu gözlenmiştir.

Harrington, Ottenbacher ve Kendall (2011) tarafından yapılan çalışmada, lüks restoranların seçim faktörlerinin ve bu faktörlerin demografik özelliklere göre değişkenlik gösterip göstermeyeceğinin belirlenmesi amaçlanmıştır. Çalışmada katılımcılara anket tekniği uygulanmış ve 574 veri elde edilmiştir. Çalışmanın sonucunda bireylerin lüks restoran seçmelerinde, 'fiyat, kalite beklentisi ve çeşitlilik en önemli etkenler olmuştur. Bunlarla birlikte, 'menü çeşitliliği, restoran imaj1, atmosfer, servis hızı ve reklam' restoran seçim kriterleri içerisinde saptanmıştır. Ayrıca, bu faktörlerin bireylerin demografik özeliklerine göre de değişiklik gösterdiği görülmüştür.

Arıker (2012) tarafından yapılan çalışmada, restoran seçim kriterleri ile bireylerin demografik özellikleri arasındaki ilişkinin belirlenmesi amaçlanmaktadır. İstanbul' da yaşayan bireyler üzerinde yapılan çalışmada, internet üzerinden restoran seçim kriterlerinin belirlenebilmesi için 471 kullanılabilir veri elde edilmiştir. Araştırmanın sonuçlarına göre, 'manzara, bahçe, bölge, ambiyans, yemek zamanı ve kiminle/ne zaman amaçla, müzik türü ve sigara alanı restoran seçim kriteri olarak belirlenmiştir. Bireylerin demografik özelliklerine göre, alkol servisi, çocuklara yönelik hizmet, kredi kartıyla ödeme imkanı, otopark bulunması, servis edilen mutfak türü, teras ve sakinlik' bir restoran seçim kriteri olarak görülmüştür.

Alonso, O'neill, Liu ve O'shea (2013) tarafından yapılan çalışmanın amacı, tüketicilerin restoran seçim kriterlerini belirlemektir. Bu doğrultuda, Güney ABD'de yaşayan 277 tüketiciden anket yoluyla veri elde edilmiştir. Araştırmanın sonucunda, tüketicilerin restoran seçimlerinin 'gida kalitesi, menü seçeneği, fiyat, servis kalitesi, yemeğin lezzeti, sağlıklı yiyecek ve temizlik gibi faktörlerden etkilendiği görülmüştür.

Albayrak (2014) tarafından yapılan çalışmanın amacı, restoran seçim faktörleri ile müşterilerin demografik özellikleri arasındaki ilişkiyi incelemektir. İstanbul'da gerçekleştirilen çalışmanın kapsamına 1.sınıf ve birden fazla farklı mutfağın ürünlerine yer veren restoranlar alınmıştır. Bu kapsamda, 14 restoran belirlenmiş ve bu restoranlara gelen müşteriler ile gerçekleştirilen anket sonucunda 353 anket değerlendirilmeye alınmıştır. Çalışmanın sonucuna göre, restoran seçimlerini etkileyen en önemli faktörlerin, 'restoran özellikleri, yiyecek ve içecekler, hizmetler ve parasal değer' olduğu görülmüştür. 'Restoranın imajının, atmosferin, temizliğin, konumun, sakinliğin ve rahatlığın' restoran seçiminde etkili olan nedenler olduğu saptanmıştır.

Yüksekbilgili (2014) tarafından, İstanbul'un Küçükçekmece ilçesinde gerçekleştirilen çalışmada, restoran seçim ölçütlerinin belirlenmesi amaçlanmıştır. Veriler 2011 yılında toplanmış olup 1298 kişi ile yüz yüze anketler gerçekleştirilmiştir. Araştırmanın sonucuna göre, farklı yaşa, eğitim düzeyine ve cinsiyete göre bireylerin restoran seçim ölçütlerindeki öncelikler farklılık göstermektedir. Araştırmada tüketicilerin restoran seçim ölçütlerinin önemi; 'servis ve sunum, garson kıyafet ve davranışları, dış görünüş, fiyat, otopark imkanı, tavsiye, mekanda müzik çalması, mekanın sakin olması ve reklamın daha önce görülmesi' şeklinde sıralanmaktadır.

Cevizkaya (2015) tarafından yapılan araştırmanın amacı, müşterilerin etnik restoranları tercih etmelerinde etkili olan faktörleri belirlemektir. İstanbul'da gerçekleştirilen çalışmada 200 müşteriye anket uygulanmıştır. Çalışmanın sonucunda tüketicilerin etnik restoranları tercih ederken, yiyeceklerin sunum kalitesine, çalışanların davranışlarına, menü çeşitliliğine, çalışanların bilgili 
olmasına, restoranın atmosferine ve restoran dekorunun etnik restorana uyumuna dikkat ettikleri görülmüştür.

Jung, Sydnor, Lee ve Almanza (2015) tarafından yapılan çalışmada, tüketicilerin restoran seçim kriterleri araştırılmıştır. Çalışma kapsamında uygulanan anketlerin analizi için 232 anket değerlendirilmeye alınmıştır. Çalışmanın sonucunda, restoranların tercih edilmesinde en baskın unsur yiyecek kalitesi olmuştur. Ardından, hizmet kalitesi ve uygun fiyat faktörlerinin etkili olduğu görülmüştür.

Karakaş, Çiçek, Ercan İştin (2015) tarafından yapılan çalışmanın amacı, yerel ve uluslararası markalı işletmelerin tercih edilme nedenlerini belirlemektir. $\mathrm{Bu}$ amaç doğrultusunda veri elde edebilmek için anket tekniği benimsenmiş ve 88 geçerli anket toplanmıştır. Çalışmanın sonucunda işletme tercihinde etkili faktörlerin, 'bilgi, kalite, güven, hijyen, lezzet, fiziksel yapı, ambiyans, servis kolaylığı, fiyat ve porsiyon' olduğu saptanmıştır.

Cömert ve Özata (2016) tarafından Ankara'da yapılan çalışmanın amacı, Karadeniz mutfağ1 sunan restoranlara giden tüketicilerin, yöresel restoranları tercih etme nedenlerini belirlemektir. Çalışma verilerini elde edebilmek için anket tekniği uygulanmış ve bu doğrultuda 250 müşteriye ulaşılmıştır. Çalışmanın sonucunda, yöre mutfağını en çok tercih eden kitlenin öğrenciler olduğu görülmüştür. Restoran seçim ölçütlerinin ise, 'yöresel ürünün lezzeti, tazeliği, sağlıklı olması, güvenilirliği ve hammaddenin yöreden temin edilmesi' olduğu sonucuna ulaşılmıştır.

Mhlanga ve Tichaawa (2016) tarafından Güney Afrika'da yapılan çalışmanın amacı, tam hizmet veren restoranlarda tüketici seçim kriterlerini etkileyen unsurları belirlemektir. Anket tekniğiyle gerçekleştirilen araştırma sonunda toplam 400 geçerli yanıt elde edilmiştir. Çalışmanın sonucunda, tüketicilerin restoran seçimlerini etkileyen en önemli unsurların, hizmet kalitesi, yiyecek kalitesi, restoranın tavsiye edilmesi ve atmosfer olduğu görülmüştür. Ayrıca bu unsurların, tüketicilerin restoranda bulunma sürelerini etkilediği ve satın almayı artırdığı sonucuna ulaşılmıştır.

Wibowo ve Tielung (2016) tarafından yapılan çalışmada, tüketicilerin franchise fast food restoranları seçmelerinde etkili olan faktörlerin belirlenmesi amaçlanmıştır. Araştırma için, belirlenen fast food restoranlarında yemek deneyimi yaşamış bireylere ulaşılmıştır. Analitik Hiyerarşi Süreci yönteminin kullanıldığ çalışmada toplam 50 katılımcıdan veri elde edilmiştir. Araştırma sonucunda, en çok tercih edilen fast food restoranının McDonald's olduğu görülmüştür. Bu restoranların seçimini etkileyen en önemli faktörün fiyat olduğu sonucuna ulaşılmış ve sırasıyla, temizlik, atmosfer, lezzet, konum ve servis faktörlerinin etkili olduğu saptanmıştır.

Sudhagar ve Rajendran (2017) tarafından Hindistan'da gerçekleştirilen çalışmanın amacı, tüketicilerin Çin restoranlarını seçmelerinde etkili olan kriterleri belirlemek ve yemek alışkanlıklarını araştırmaktır. Bu amaçla gerçekleştirilen çalışmada anket kullanılmış ve analiz için geçerli 126 anket elde edilmiştir. Çalışmanın sonucunda, müşterilerin en çok, yiyecek kalitesine, servis kalitesine, hijyen ve temizliğe, çevre kalitesine ve parasal değere dikkat ettikleri görülmüsstür.

Badem ve Öztel (2018) tarafından yapılan çalışmada, müşterilerin restoran seçimlerini etkileyen faktörlerin araştırılması ve bu faktörlerin birbirleri ile arasındaki ilişkilinin incelenmesi amaçlanmıştır. Bu amacın gerçekleştirilebilmesi için DEMATEL metodu uygulanmıştır. Uygulanan metodun sonucunda, restoran seçim kriterlerinin önem sırasının, 'hizmet kalitesi, ürün kalitesi, personel kalitesi, atmosfer ve fiyat' olarak sıralandığ belirlenmiştir.

Canoğlu ve Ballı (2018) tarafından Adana ilinde yapılan çalışmada, tüketicilerin kebap restoranı tercihinde önemli olan unsurların ve bu unsurların bireylerin demografik üzerine farklılık gösterip göstermediğinin belirlenmesi amaçlanmıştır. $\mathrm{Bu}$ kapsamda, Adana ili kebap restoranlarında yemek yemeyi tercih eden bireyler üzerinde anket uygulanmış ve toplamda 530 veriye ulaşılmıştır. Çalışmanın sonucunda, tüketicilerin restoran seçim kriterlerinin önem sırasının, 'hizmet, atmosfer, yiyecekler ve kolaylıklar' şeklinde olduğu görülmüştür. Ayrıca, bireylerin demografik özelliklerine göre restoran seçim kriterlerinin öneminde farklılık olduğu gözlenmiştir. 
Çakıcı ve Yıldız (2018) tarafından Kayseri'de yapılan çalışmada, restoran tercihlerine etki eden faktörlerin belirlenmesi ve bu faktörlere göre bireylerin kümelendirilmesi amaçlanmıştır. Bu amaç doğrultusunda, Kayseri'de yaşayan bireylere anket uygulanmış olup toplamda 577 anket elde edilmiştir. Çalışmanın sonuçlarına göre, restoran tercihini etkileyen kriterler 6 boyutta toplanmıştır. Bunlar, 'hizmet kalitesi, belirleyici unsurlar, sağlıklı yiyecekler, fiyat kolaylıkları, tanıtım ve rahatlık' faktörleri olmuştur. Bu kapsamda restoran müşterileri 'seçiciler' ve 'umursamazlar' olarak iki gruba ayrılmış ve gruplar ile demografik özellikler arasında anlamlı bir ilişki olduğu saptanmıştır.

Akgündüz, Akdağ ve Metin (2019) tarafından Mersin ilinde yapılan çalışmada, restoran tercihini etkileyen unsurların ve bunların sadakat üzerindeki etkilerinin belirlenmesi amaçlanmıştır. Araştırma kapsaminda, Mersin ilinde bulunan restoranlara giden müşteriler üzerinde anket uygulanmış ve analiz için 387 kullanılabilir anket elde edilmiştir. Çalışmada, restoranların tercih edilme nedenlerinin, 'restoran özellikleri, kolaylıklar, servis, personel kalitesi, menü, sipariş ve yiyecekler' olduğu sonucuna ulaşılmıştır. Restoran özellikleri içerisinde restoranın manzarası, yeri, atmosferi ve dekoru; kolaylıklar içerisinde çocuk menüsü, park imkanı, engelli hizmeti gibi unsurların önemli olduğu gözlenmiştir. Bununla birlikte, restoran özelliklerinin ve kolaylıkların müşteri sadakatini artırdığı görülmüştür.

Araz (2019) tarafından, Kapadokya'ya gelen turistlerin restoran seçimlerinde bireylerin kişilik ve demografik özelliklerinin fark oluşturup oluşturmadığını belirlemek amacıyla yaptığı çalışmada, katılımcılara anket uygulanmış ve toplam 404 analiz edilebilir anket elde edilmiştir. Çalışmanın sonucunda, cinsiyet dişında bireylerin demografik özelliklerine göre farklılık olduğu saptanmıştır. Turistler için restoran seçim ölçütlerindeki önceliklere bakıldığında, 'personel kalitesi, yiyecek içecekler, restoran özellikleri ve kolaylıklar' şeklinde olduğu sonucuna ulaşılmıştır. Yiyecek ve içecekler faktörü içerisinde, tazelik ve yiyeceğin lezzetinin; restoran özellikleri faktörü içerisinde, restoranın ısısının ve temizliğin; kolaylıklar içerisinde ise, menü kartlarının anlaşılırlığının, internet ve engelli hizmetinin önemli görüldüğü saptanmıştır.

Aşık (2019) tarafından İzmir ilinde yapılan çalışmada, çocuklu ailelerin restoran seçim kriterleri ve bu kriterlerin bireylerin sosyo-demografik özelliklerine göre farklılık oluşturup oluşturmadığını belirlemektedir. Bu amaç doğrultusunda, 6 yaşından küçük en az bir çocuğu olan ailelere anket uygulanmış ve toplam 400 geçerli anket elde edilmiştir. Çalışmanın sonucunda restoran seçim kriterleri, 'yemeklerin özellikleri, restoranın özellikleri, parasal değer ve çocuk dostu hizmetler' olarak belirlenmiştir. Bulgular, çocuklu aileler için 'sağlık, hijyen, güvenilirlik, rahatlık ve çocukların zaman geçirebilecekleri bir alanın olması' unsurlarının önem arz ettiğini göstermiştir. Restoran seçim kriterlerinde önemli olan bu faktörlerin, eğitim, gelir, meslek, yaş, restorana gitme sıklığı ve restoranın çeşidine göre farklılık gösterdiği sonucuna ulaşılmıştır.

Emir ve Özdemir (2019) tarafından yapılan çalışmanın amacı, Türk müşterilerin kültürel değerlerinin restoran tercihlerine etkisini belirlemektir. Amerika Birleşik Devletleri'nin New York şehrinde yaşayan 384 Türk müşteriye anket uygulanmıştır. Çalışmanın sonucunda, kültürel değerlerin restoran seçiminde etkili olduğu görülmüştür. Etkili olan kültürel değerler içerisinde en etkili boyut personel boyutu olmuştur. Ardından, farklı kültür, yemek/menü çeşitliliği ve atmosferin en etkili boyutlar olduğu görülmüştür. Dolayısıyla müşteriler, tercih ettikleri restoranda çalışan personelin bireyin kültürüne olan aşinalığına, farklı kültürler deneyimleme isteğine, kendi kültürlerine ait menülerin çeşitliliğine ve işletmede yaratılan kültüre özgü atmosfere dikkat etmektedir. Bununla birlikte, 56 yaş ve üzeri bireyler ile haftada en az bir defa restorana giden bireylerin diğer gruplara göre kültürel değerlere daha fazla önem verdiği görülmüsstür.

Kurnaz ve Şengül (2019) tarafından yapılan çalışmanın amacı, Marmaris'i ziyaret eden yerli turistlerin etnik restoran seçim kriterlerine yönelik algıları ve seçim kriterleri ile demografik farklılıkları arasındaki ilişkiyi incelemektir. Marmaris'te etnik restorana giden 404 yerli turiste anket uygulanmıştır. Araştırma sonucunda turistlerin, aile gezisi, sosyalleşme fırsatı ve zevk alma gibi sebeplerle etnik restoranları tercih ettikleri ortaya çıkmıştır. Bu tercihlerde etkili olan önemli faktörler, etnik restoranın atmosferi, servis personelinin tutumu ve yemek kalitesi olmuştur. Daha 
az etkili olan faktörlerin ise, reklam, çocuklar için olanaklar ve açılış saati olduğu görülmüştür. Ayrıca, yaş, medeni durum ve gelir açısından restoran seçim kriterleri arasında anlamlı bir farklılık görülürken, cinsiyet bakımından bir farklılık gözlenmemiştir.

Chua, Karim, Lee ve Han (2020) tarafından yapılan çalışmanın amacı, tüketicilerin restoran seçimlerinde etkili olan faktörleri belirlemektir. Amaç doğrultusunda bireylere anket dağıtılmış ve 539 geçerli anket elde edilmiştir. Analiz sonucunda restoran seçimini etkileyen en önemli faktörün fiyat olduğu görülmüştür. Diğer önemli faktörler ise, ağızdan ağıza tavsiye, geçmiş deneyimler, menü çeşitleri, popülerlik, marka itibarı ve konum şeklinde sıralanmıştır.

Oğuzalp (2020) tarafından KTO Karatay Üniversitesi'nde yapılan çalışmanın amacı, öğrencilerin restoran seçim ölçütlerinin demografik özelliklere göre farklılaşıp farklılaşmadığını belirlemektir. Bu amaç doğrultusunda, 329 öğrenciye anket uygulanmıştır. Çalışmanın sonucunda, üniversite öğrencilerinin daha çok gündelik restoranları tercih ettiği görülmüştür. Bu restoranlara ise, daha çok açlığ1 giderilmek ve arkadaşlarla güzel vakit geçirmek amacıyla gittikleri görülmüştür. Ayrıca, restoran tercihlerinde en çok hizmet kalitesine, uygun fiyata ve temizlik faktörlerine önem verdikleri görülmüştür.

Türkay ve Atasoy (2020) tarafından yapılan çalışmada, müşterilerin restoran seçim tercihleri ile kişilik özellikleri arasındaki ilişkinin belirlenmesi amaçlanmıştır. Sakarya' nın Serdivan ilçesinde bulunan restoranların ele alındığı çalışmada 448 katılımcıya anket uygulanmıştır. Çalışmanın sonucunda, müşterilerin restoran seçim tercihlerinde en önemli gördükleri faktörlerin, 'personelin tutum ve davranışları, maliyet kalitesi, müzik ve restoranın fiziksel özellikleri’ olduğu görülmüştür. Ayrıca, kişilik özelliklerinin, restoran seçim tercihleri üzerinde farklılık gösterdiği saptanmıştır.

Tüketicilerin restoran seçim ölçütlerini belirleyen ulusal ve yabancı birçok çalışma yapılmıştır. $\mathrm{Bu}$ çalışmalar, farklı bölgelere, mekanlara ve müşteri kitlelerine uygulanarak birbirlerinden farklı özellikler taşımaktadırlar. İncelenen literatürle, müşterilerin çok fazla kriteri dikkate aldığ1 anlaşılmaktadır. Çalışmalarda belirlenen kriterlerin ise çoğunlukla aynı olmakla birlikte, restoranın konseptine göre ve tüketicilerin bireysel özelliklerine göre değişebildiği görülmektedir. Literatür taraması ile belirlenen tüketicilerin restoran seçim ölçütleri, tablo halinde 'Bulgular' başlığında verilmiştir.

\section{YÖNTEM}

$\mathrm{Bu}$ çalışmada, tüketicilerin restoran seçim ölçütleri üzerine yapılmış tezler, makaleler ve bildiriler incelenmiştir. Araştırmada literatür taramasına dayalı bibliyografik yöntem kullanılmıştır. Bibliyografya çalışmaları, farklı yayınlarda ve kütüphanelerde bulunan, belirli bir konuya, yazara veya coğrafyaya ait çalışmaların bir araya getirilerek içeriklerinin belirli ipuçları ile düzenlendiği çalışmalardır. Bu çalışmalar, bilgiye ulaşma bakımından araştırmacıya rehberlik ederek araştırmacının yolunu aydınlatmaktadır. Aynı zamanda, araştırmacıya yeni fikirler kazandırmaktadır (Tuna, 2017: 126). 'Tüketicilerin Restoran Seçim Ölçütleri' konulu çalışmaların bir araya getirilmesi için yapılan literatür taraması sonucunda, 26 makale, 3 tez ve 1 bildiri incelenmiştir. İncelenen çalışmaların 17 tanesi ulusal, 13 tanesi ise yabancı çalışmalardır. Yapılan çalışmanın güncel olabilmesi için tarama sonucunda 2000 yılı altındaki çalışmalar kapsam dışı bırakılmıştır. Dolayısıyla, 2002-2020 yılları arasında konu ile ilgili yapılan çalışmalar ele alınmıştır. 


\section{BULGULAR}

Tablo 1- Restoran Seçim Ölçütleri Üzerine Yapılan Çalışmalarda Belirlenen Kriterler

\begin{tabular}{|c|c|c|}
\hline $\begin{array}{l}\text { Yazar/ } \\
\text { Yazarlar }\end{array}$ & Y1l & $\begin{array}{l}\text { Restoran Seçim } \\
\text { Kriterleri }\end{array}$ \\
\hline Heung & 2002 & $\begin{array}{ll}\text { - } & \text { Yiyecek kalitesi } \\
\text { - } & \text { Servis personelinin } \\
& \text { tutumu } \\
\text { - } & \text { Paranın değeri } \\
\text { - } & \text { Atmosfer } \\
\end{array}$ \\
\hline Cullen & 2005 & $\begin{array}{ll}\text { - } & \text { Yiyecek kalitesi } \\
\text { - } & \text { Yiyecek türü } \\
\text { - } & \text { Konum } \\
\text { - } & \text { Temizlik } \\
\text { - } & \text { Atmosfer } \\
\text { - } & \text { Imaj } \\
\text { - } & \text { Hizmet kalitesi } \\
\end{array}$ \\
\hline $\begin{array}{l}\text { Tayfun ve } \\
\text { Tokmak }\end{array}$ & 2007 & $\begin{array}{ll}\text { - } & \text { Menünün doyurucu } \\
\text { olması } \\
\text { - } & \text { Damak tadına } \\
& \text { uygun menü } \\
& \text { sunumu } \\
\text { - } & \text { Hizmet } \\
\text { - } & \text { Ulaşım kolaylığı }\end{array}$ \\
\hline Batra & 2008 & $\begin{array}{ll}\text { - } & \text { Yemeğin lezzeti } \\
\text { - } & \text { Otantik pişirme } \\
\text { - } & \text { Yemeklerin } \\
& \text { görünümü } \\
\text { - } & \text { Sağlıklı yiyecek } \\
\text { - } & \text { Menü } \\
\text { - } & \text { Dekor } \\
\text { - } & \text { Atmosfer } \\
\text { - } & \text { Evde hazırlanması } \\
& \text { zor olan yemekler } \\
\end{array}$ \\
\hline $\begin{array}{l}\text { Njite, Dunn } \\
\text { ve Kim }\end{array}$ & 2008 & $\begin{array}{ll}\text { - } & \text { Müşteri ilişkileri } \\
\text { - } & \text { Fiyat } \\
\text { - } & \text { Atmosfer } \\
\text { - } & \text { Çalışanın yetkinliği } \\
\text { - } & \text { Rahatlık } \\
\end{array}$ \\
\hline $\begin{array}{l}\text { Choi ve } \\
\text { Zhao }\end{array}$ & 2010 & $\begin{array}{ll}\text { - } & \text { Restoranın ortamı } \\
\text { - } & \text { Ekonomik değer } \\
\text { - } & \text { Atmosfer } \\
\text { - } & \text { Hizmet } \\
\text { - } & \text { Sağlıklı yiyecekler } \\
\text { - } & \text { Fiyat } \\
\text { - } & \text { Porsiyon boyutu } \\
\end{array}$ \\
\hline $\begin{array}{l}\text { Kim, Raab } \\
\text { ve Bergman }\end{array}$ & 2010 & $\begin{array}{ll}\text { - } & \text { Yiyeceğin ve } \\
& \text { içeceğin lezzeti } \\
\text { - } & \text { Yiyeceğin ve } \\
& \text { içeceğin kalitesi } \\
\text { - } & \text { Hizmet kolaylığı } \\
\text { - } & \text { Menü çeşitliliği } \\
\text { - } & \text { Otopark } \\
\end{array}$ \\
\hline $\begin{array}{l}\text { Harrington, } \\
\text { Ottenbacher } \\
\text { ve Kendall }\end{array}$ & 2011 & $\begin{array}{ll}\text { - } & \text { Reklam } \\
\text { - } & \text { Fiyat } \\
\text { - } & \text { Kalite } \\
\text { - } & \text { Menü çeşitliliği } \\
\text { - } & \text { Servis hizı } \\
\text { - } & \text { Atmosfer } \\
\text { - } & \text { Restoran İmaji }\end{array}$ \\
\hline
\end{tabular}

\begin{tabular}{|c|c|c|}
\hline Arıker & 2012 & $\begin{array}{ll}\text { - } & \text { Manzara } \\
\text { - } & \text { Yemek türü } \\
\text { - } & \text { Alkol } \\
\text { - } & \text { Bölge } \\
\text { - } & \text { Fiyat } \\
\text { - } & \text { Bahçe } \\
\text { - } & \text { Ambiyans } \\
\text { - } & \text { Otopark } \\
\text { - } & \text { Çocuklarla ilgili } \\
& \text { kriterler } \\
\text { - } & \text { Yemek zamanı } \\
\text { - } & \text { Teras } \\
\text { - } & \text { Mutfak türü } \\
\end{array}$ \\
\hline $\begin{array}{l}\text { Alonso, } \\
\text { O'neill, Liu } \\
\text { ve O'shea }\end{array}$ & 2013 & $\begin{array}{ll}\text { - } & \text { Yiyeceğin kalitesi } \\
\text { - } & \text { Menü seçeneği } \\
\text { - } & \text { Servis kat } \\
\text { - } & \text { Yemeğin lezzeti } \\
\text { - } & \text { Sağliklı yiyecek } \\
\text { - } & \text { Temizlik } \\
\end{array}$ \\
\hline Yüksekbilgili & 2014 & $\begin{array}{ll}\text { - } & \text { Servis ve sunum } \\
\text { - } & \text { Garson kıyafet ve } \\
& \text { davranışları } \\
\text { - } & \text { Diş görünüş } \\
\text { - } & \text { Fiyat } \\
\text { - } & \text { Otopark imkânı } \\
\text { - } & \text { Tavsiye } \\
\text { - } & \text { Müzik } \\
\text { - } & \text { Sakinlik } \\
\end{array}$ \\
\hline Albayrak & 2014 & $\begin{array}{ll}\text { - } & \text { Restoran özellikleri } \\
\text { - } & \text { Yiyecek ve içecekler } \\
\text { - } & \text { Hizmet } \\
\text { - } & \text { Parasal değer } \\
\text { - } & \text { Atmosfer } \\
\text { - } & \text { Restoranın } \\
& \text { bilinirliliği (imajı) } \\
\text { - } & \text { Temizlik } \\
\text { - } & \text { Konum } \\
\text { - } & \text { Rahatlık } \\
\text { - } & \text { Kalabalık olmaması } \\
\end{array}$ \\
\hline Cevizkaya & 2015 & $\begin{array}{ll}\text { - } & \text { Yiyeceklerin sunum } \\
& \text { kalitesi } \\
\text { - } & \text { Menü çeşitliliği } \\
\text { - } & \text { Çalışanların } \\
& \text { davranışları } \\
\text { - } & \text { Çalışanların bilgili } \\
& \text { olması } \\
\text { - } & \text { Restoranın atmosferi } \\
\text { - } & \text { Restoran dekorunun } \\
& \text { etnik restorana } \\
& \text { uyumu } \\
\end{array}$ \\
\hline $\begin{array}{l}\text { Jung, } \\
\text { Sydnor, Lee } \\
\text { ve Almanza }\end{array}$ & 2015 & $\begin{array}{ll}\text { - } & \text { Yiyecek kalitesi } \\
\text { - } & \text { Hizmet kalitesi } \\
\text { - } & \text { Uygun fiyat }\end{array}$ \\
\hline
\end{tabular}




\begin{tabular}{|c|c|c|}
\hline $\begin{array}{l}\text { Karakaş, } \\
\text { Çiçek ve } \\
\text { İştin }\end{array}$ & 2015 & $\begin{array}{ll}\text { - } & \text { Bilgi } \\
\text { - } & \text { Kalite } \\
\text { - } & \text { Güven } \\
\text { - } & \text { Lezzyen } \\
\text { - } & \text { Fiziksel yapı } \\
\text { - } & \text { Ambiyans } \\
\text { - } & \text { Servis kolaylığ } 1 \\
\text { - } & \text { Fiyat } \\
\text { - } & \text { Porsiyon } \\
\end{array}$ \\
\hline $\begin{array}{l}\text { Cömert ve } \\
\text { Özata }\end{array}$ & 2016 & $\begin{array}{ll}\text { - } & \text { Yöresel ürünün } \\
& \text { lezzeti } \\
\text { • } & \text { Yöresel ürünün } \\
& \text { tazeliği } \\
\text { • } & \text { Sağlıklı olması } \\
\text { • } & \text { Güvenilirliği } \\
\text { - } & \text { Hammaddenin } \\
& \text { yöreden temin } \\
\text { edilmesi }\end{array}$ \\
\hline $\begin{array}{l}\text { Mhlanga ve } \\
\text { Tichaawa }\end{array}$ & 2016 & $\begin{array}{ll}\text { - } & \text { Hizmet kalitesi } \\
\text { - } & \text { Yiyecek kalitesi } \\
\text { - } & \text { Atmosfer } \\
\text { - } & \text { Restoranin tavsiye } \\
& \text { edilmesi } \\
\end{array}$ \\
\hline $\begin{array}{l}\text { Wibowo ve } \\
\text { Tielung }\end{array}$ & 2016 & $\begin{array}{ll}\text { - } & \text { Fiyat } \\
\text { - } & \text { Temizlik } \\
\text { - } & \text { Atmosfer } \\
\text { - } & \text { Lezzet } \\
\text { - } & \text { Konum } \\
\text { - } & \text { Servis } \\
\end{array}$ \\
\hline $\begin{array}{l}\text { Sudhagar ve } \\
\text { Rajendran }\end{array}$ & 2017 & $\begin{array}{ll}\text { - } & \text { Yiyecek kalitesi } \\
\text { - } & \text { Servis kalitesi } \\
\text { - } & \text { Hijyen ve temizlik } \\
\text { - } & \text { Çevre kalitesi } \\
\text { - } & \text { Parasal değer }\end{array}$ \\
\hline $\begin{array}{l}\text { Badem ve } \\
\text { Öztel }\end{array}$ & 2018 & $\begin{array}{ll}\text { - } & \text { Hizmet kalitesi } \\
\text { - } & \text { Ürün kalitesi } \\
\text { - } & \text { Personel kalitesi } \\
\text { - } & \text { Atmosfer } \\
\text { - } & \text { Fiyat }\end{array}$ \\
\hline $\begin{array}{l}\text { Canoğlu ve } \\
\text { Ballı }\end{array}$ & 2018 & $\begin{array}{ll}\text { - } & \text { Hizmet } \\
\text { - } & \text { Atmosfer } \\
\text { - } & \text { Yiyecekler } \\
\text { - } & \text { Kolayliklar } \\
\end{array}$ \\
\hline $\begin{array}{l}\text { Çakılcı ve } \\
\text { Yıldız }\end{array}$ & 2018 & $\begin{array}{ll}\text { - } & \text { Hizmet kalitesi } \\
\text { - } & \text { Sağlıklı yiyecekler } \\
\text { - } & \text { Fiyat } \\
\text { - } & \text { Rahatlık } \\
\text { - } & \text { Tanitım }\end{array}$ \\
\hline $\begin{array}{l}\text { Akgündüz, } \\
\text { Akdağ ve } \\
\text { Metin }\end{array}$ & 2019 & $\begin{array}{ll}\text { - } & \text { Manzara } \\
\text { - } & \text { Atmosfer } \\
\text { - } & \text { Konum } \\
\text { - } & \text { Çocuk menüsü } \\
\text { - } & \text { Otopark } \\
\text { - } & \text { Engelli hizmeti } \\
\end{array}$ \\
\hline
\end{tabular}

\begin{tabular}{|c|c|c|}
\hline & & $\begin{array}{ll}\text { - } & \text { Servis } \\
\text { - } & \text { Personel kalitesi } \\
\text { - } & \text { Menü } \\
\end{array}$ \\
\hline Araz & 2019 & $\begin{array}{ll}\text { - } & \text { Personel kalitesi } \\
\text { - } & \text { Tazelik } \\
\text { - } & \text { Yiyeceklerin lezzeti } \\
\text { - } & \text { Temizlik } \\
\text { - } & \text { Restoranın ısısı } \\
\text { - } & \text { Kolayliklar } \\
\text { - } & \text { Menü kartlarının } \\
& \text { anlaşıllurlığ1 } \\
\text { - } & \text { Engelli hizmeti } \\
\text { - } & \text { İnternet hizmeti } \\
\end{array}$ \\
\hline Aşık & 2019 & $\begin{array}{ll}\text { - } & \text { Yemeklerin } \\
& \text { özellikleri } \\
\text { - } & \text { Parasal değer } \\
\text { - } & \text { Çocuk dostu } \\
& \text { hizmetler } \\
\text { - } & \text { Sağlık } \\
\text { - } & \text { Hijyen } \\
\text { - } & \text { Güvenilirlik } \\
\text { - } & \text { Rahatlık } \\
\text { - } & \text { Çocukların zaman } \\
& \text { geçirebilecekleri alan } \\
\end{array}$ \\
\hline $\begin{array}{l}\text { Emir ve } \\
\text { Özdemir }\end{array}$ & 2019 & $\begin{array}{ll}\text { - } & \text { Personel } \\
\text { - } & \text { Farklı kültür } \\
\text { - } & \text { Yemek/Menü } \\
& \text { çeşitliliği } \\
\text { - } & \text { Atmosfer } \\
\end{array}$ \\
\hline $\begin{array}{l}\text { Kurnaz ve } \\
\text { Şengül }\end{array}$ & 2019 & $\begin{array}{ll}\text { - } & \text { Atmosfer } \\
\text { - } & \text { Yemek kalitesi } \\
\text { - } & \text { Servis personelinin } \\
& \text { tutumu } \\
\text { - } & \text { Reklam } \\
\text { - } & \text { Çocuklar için } \\
& \text { olanaklar } \\
\text { - } & \text { Açlliş saati } \\
\end{array}$ \\
\hline $\begin{array}{l}\text { Chua, } \\
\text { Karim, Lee } \\
\text { ve Han }\end{array}$ & 2020 & $\begin{array}{ll}\text { - } & \text { Fiyat } \\
\text { - } & \text { Ağıdan ağıza } \\
& \text { tavsiye } \\
\text { - } & \text { Geçmiş deneyimler } \\
\text { - } & \text { Menü çeşitleri } \\
\text { - } & \text { Popülerlik } \\
\text { - } & \text { Marka itibarı } \\
\text { - } & \text { Konum } \\
\end{array}$ \\
\hline Oğuzalp & 2020 & $\begin{array}{ll}\text { - } & \text { Hizmet kalitesi } \\
\text { - } & \text { Uygun fiyat } \\
\text { - } & \text { Temizlik } \\
\end{array}$ \\
\hline $\begin{array}{l}\text { Türkay ve } \\
\text { Atasoy }\end{array}$ & 2020 & $\begin{array}{ll}\text { - } & \text { Personelin tutum ve } \\
\text { - } & \text { davranısları } \\
\text { - } & \text { Mäiyet kalitesi } \\
\text { - } & \text { Restoranın fiziksel } \\
& \text { özellikleri } \\
\end{array}$ \\
\hline
\end{tabular}


Tablo 1'de restoran seçim ölçütlerinin belirlendiği çalışmalara ve bu çalışmaların sonucunda ortaya çıkan seçim kriterlerine yer verilmiştir. Çalışmaların yapıldı̆̆ı yıllar dikkate alındığında, konunun son yıllarda sık sık çalışıldığ1 görülmüştür. Yer verilen çalışmaların 5 tanesinin özel mutfağa sahip restoranlar, 2 tanesinin fast food restoranlar, 3 tanesinin etnik restoranlar, 4 tanesinin lüks restoranlar, 1 tanesinin zincir restoranlar ve diğerlerinin tam hizmet sunan klasik restoranlar üzerinde yapıldığı saptanmıştır. Özel mutfağa sahip restoranlar üzerinde yapılan çalışmaların, Amerikan mutfağı, Çin mutfağı, Türk mutfağı, Karadeniz mutfağı sunan ve kebap satışı yapan restoranlarda yapıldığı görülmüştür (Heung, 2002; Cömert ve Özata, 2016; Sudhagar ve Rajendran, 2017; Canoğlu ve Ballı, 2018; Emir ve Özdemir, 2019). Bu çalışmalara bakıldığında genel olarak yiyecek kalitesi, hizmet kalitesi ve atmosferin yer aldığg görülmektedir. Dolayısıyla tüketicilerin, özel bir mutfağı sunan restoranları tercih ederken en çok bu faktörleri dikkate aldığ1 söylenebilmektedir. Fast food restoranların seçim kriterlerini ise, Tayfun ve Tokmak (2007), Wibowo ve Tielung (2016) yaptıkları çalışmalar ile belirlemişlerdir. Bu çalışmalarda tüketicilerin, bir restoranı seçerken fiyat, menünün doyurucu olması ve konum gibi faktörleri önemsediği görülmüştür. Etnik restoranlar üzerine yapılan çalışmalarda (Batra, 2008; Cevizkaya, 2015; Kurnaz ve Şengül, 2019) ise, tüketicilerin bu restoranları seçerken, yiyeceğin sunumuna, kalitesine, atmosfere, restoranın dekoruna ve servis personelinin tecrübesine önem gösterdiğine yer verilmiştir. Ayrıca otantik pişirme ve dekorun etnik restorana uyumu şeklindeki faktörlerden, tüketicilerin etnik restoranlarda, etnik havayı hissetmek istedikleri anlaşılmaktadır. Tüketicilerin lüks restoranları seçme ölçütlerine ilişkin yapılan çalışmalar, Njite ve diğerleri (2008), Kim ve diğerleri (2010), Harrington ve diğerleri (2011), Albayrak (2014) tarafından yapılan çalışmalardır. Bu çalışmalarda tüketicilerin özellikle, fiyat, kalite, müşteri ilişkileri, çeşitlilik, sakinlik ve atmosfer faktörlerini kriter olarak benimsediği saptanmıştır. Kim ve diğerleri (2010) tarafından yapılan çalışmada, lüks restoranların yanı sıra gündelik restoranların ve açık büfe restoranların da seçim kriterlerine yer verilmiştir. Tüketicilerin gündelik restoranları seçim kriterleri, yiyecek içeceğin lezzeti ve kalitesi ile hizmet kolaylı̆̆ı şeklindedir. Açı büfe restoranların seçilmesinde önemli rol oynayan faktörlerin ise, menü çeşitliliği, yiyecek içeceğin lezzeti ve kalitesi ile otopark imkanı olduğu görülmüştür. Karakaş ve diğerleri (2015) tarafında yapılan çalışma, yerel ve uluslararası markalı işletmelerin seçim kriterlerini belirlemiştir. Bu doğrultuda, tüketicilerin zincir restoranları seçerken önemli gördükleri faktörlerin, bilgi, kalite, güven, hijyen, lezzet, fiziksel yapı vb. şeklinde olduğu belirtilmiştir. Çocuklu ailelerin bir restoran seçerken hangi faktörlere dikkat ettiğini belirten çalışmada (Aşık, 2019), yemeklerin özellikleri, parasal değer, çocuk dostu hizmetler, sağlık, hijyen ve çocukların zaman geçirebilecekleri alan faktörlerinin tüketiciler için önemli olduğu saptanmıştır. Çocuklu ailelerin restorana gittiklerinde, çocukları için bir kolaylık beklediği görülmektedir. Öğrenciler üzerine yapılan çalışmada (Oğuzalp, 2020) ise, öğrencilerin restoranda hizmet kalitesine, uygun fiyata ve temizliğe dikkat ettiği görülmüştür. Yapılan diğer çalışmalarda belirtilen kriterler, yiyecek kalitesi, yiyecek türü, konum, temizlik, atmosfer, imaj, hizmet kalitesi, fiyat, porsiyon, manzara, kolayliklar, müzik, sakinlik, reklam ve deneyim şeklindedir (Cullen, 2005; Choi ve Zhao, 2010; Alonso ve diğerleri, 2013; Yüksekbilgili, 2014; Jung ve diğerleri, 2015; Mhlanga ve Tichaawa, 2016; Çakıcı ve Yıldız, 2018; Akgündüz ve diğerleri, 2019; Araz, 2019; Chua ve diğerleri, 2020; Türkay ve Atasoy, 2020). 
Tablo 2- Restoran Seçim Ölçütlerinin Restoranın Temasına Göre Bölümlendirilmesi

\begin{tabular}{|c|c|c|c|}
\hline $\begin{array}{c}\text { Restoranın } \\
\text { Teması }\end{array}$ & Seçim Ölçütleri & $\begin{array}{c}\text { Restoranın } \\
\text { Temasi }\end{array}$ & Seçim Ölçütleri \\
\hline $\begin{array}{c}\text { Standart (Tema } \\
\text { belirtilmeyen) } \\
\text { Restoranlar }\end{array}$ & $\begin{array}{ll}\text { - } & \text { Yiyecek kalitesi } \\
\text { - } & \text { Yiyecek türü } \\
\text { - } & \text { Konosfer } \\
\text { - } & \text { Sakinlik } \\
\text { - } & \text { Temizlik } \\
\text { - } & \text { Restoran imaji } \\
\text { - } & \text { Hizmet kalitesi } \\
\text { - } & \text { Sağlıklı yiyecekler } \\
\text { - } & \text { Üün fiyatı } \\
\text { - } & \text { Porsiyon boyutu } \\
\text { - } & \text { Yiyeceğin lezzeti } \\
\text { - } & \text { Otopark } \\
\text { - } & \text { Manzara } \\
\text { - } & \text { Bahçe } \\
\text { - } & \text { Bölge } \\
\text { - } & \text { Müzik türü } \\
\text { - } & \text { Sigara alanı } \\
\text { - } & \text { Menü seçeneği } \\
\text { - } & \text { Servis ve sunum } \\
\text { - } & \text { Personelin kiyafeti ve davranışları } \\
\text { - } & \text { Marka itibarı } \\
\text { - } & \text { Popülerlik } \\
\text { - } & \text { Çocuk menüsü } \\
\text { - } & \text { Engelli hizmeti } \\
\text { - } & \text { Tavsiye } \\
\text { - } & \text { Dekor }\end{array}$ & Lüks Restoranlar & $\begin{array}{ll}\text { - } & \text { Müşteri ilişkileri } \\
\text { - } & \text { Fiyat } \\
\text { - } & \text { Atmosfer } \\
\text { - } & \text { Çalışanın yetkinliği } \\
\text { - } & \text { Rahatlık } \\
\text { - } & \text { Hizmet kalitesi } \\
\text { - } & \text { Menü çeşitliliği } \\
\text { - } & \text { Servis hızı } \\
\text { - } & \text { Reklam } \\
\text { - } & \text { Çeşitlilik } \\
\text { - } & \text { Restoran imajı } \\
\text { - } & \text { Temizlik } \\
\text { - } & \text { Konum } \\
\text { - } & \text { Sakinlik } \\
\text { - } & \text { Restoranın tavsiye edilmesi } \\
\text { - } & \text { Yiyecek kalitesi } \\
& \end{array}$ \\
\hline $\begin{array}{l}\text { Amerikan } \\
\text { Temalı } \\
\text { Restoranlar }\end{array}$ & $\begin{array}{ll}\text { - } & \text { Yiyecek } \\
\text { - } & \text { Servis } \\
\text { - } & \text { Fiyat } \\
\text { - } & \text { Atmosfer } \\
\text { - } & \text { Çekicilik } \\
& \end{array}$ & $\begin{array}{c}\text { Yerel ve } \\
\text { Uluslararası } \\
\text { Markalı } \\
\text { Restoranlar }\end{array}$ & $\begin{array}{ll}\text { - } & \text { Bilgi } \\
\text { - } & \text { Kalite } \\
\text { - } & \text { Güven } \\
\text { - } & \text { Hijyen } \\
\text { - } & \text { Lezzet } \\
\text { - } & \text { Amiziksel yapiyans } \\
\text { - } & \text { Servis kolayliğ1 } \\
\text { - } & \text { Fiyat } \\
\text { - } & \text { Porsiyon }\end{array}$ \\
\hline $\begin{array}{l}\text { Türk Usulü } \\
\text { Fastfood } \\
\text { Restoranlar }\end{array}$ & $\begin{array}{ll}\text { - } & \text { Menülerin doyurucu olması } \\
\text { - } & \text { Damak tadına uygun olması } \\
\text { - } & \text { Menü sunumu } \\
\text { - } & \text { Olmasmetin zamanında ve hızlı } \\
\text { - } & \text { Restorim kolaylığı } \\
& \text { olması işyerine ve eve yakın }\end{array}$ & $\begin{array}{c}\text { Karadeniz } \\
\text { Mutfağı Sunan } \\
\text { Restoranlar }\end{array}$ & $\begin{array}{ll}\text { - } & \text { Yöresel ürünün lezzeti } \\
\text { - } & \text { Yöresel ürünün tazeliği } \\
\text { - } & \text { Yöresel ürünün sağlıklı } \\
& \text { olması } \\
\text { - } & \text { Güvenilirliği } \\
\text { - } & \text { Hammaddenin } \\
& \text { temin edilmesi }\end{array}$ \\
\hline $\begin{array}{c}\text { Etnik } \\
\text { Restoranlar }\end{array}$ & $\begin{array}{ll}\text { - } & \text { Yemeğin tadı } \\
\text { - } & \text { Otantik pişirme } \\
\text { - } & \text { Etnik yemeklerin görünümü } \\
\text { - } & \text { Sağlıklı yiyecek ve menü } \\
\text { - } & \text { Fiyat } \\
\text { - } & \text { Atmosfer } \\
\text { - } & \text { Çalışanın yetkinliği } \\
\text { - } & \text { Rahatlık } \\
\text { - } & \text { Kalite } \\
\text { - } & \text { Menü çeşitliliği } \\
\text { - } & \text { Servis hizı } \\
\end{array}$ & $\begin{array}{c}\text { Franchise } \\
\text { Fastfood } \\
\text { Restoranlar }\end{array}$ & $\begin{array}{ll}\text { - } & \text { Fiyat } \\
\text { - } & \text { Temizlik } \\
\text { - } & \text { Atmosfer } \\
\text { - } & \text { Lezzet } \\
\text { - } & \text { Konum } \\
\text { - } & \text { Servis }\end{array}$ \\
\hline
\end{tabular}




\begin{tabular}{|c|c|c|c|}
\hline & $\begin{array}{ll}\text { - } & \text { Reklam } \\
\text { - } & \text { Sunum kalitesi } \\
\text { - } & \text { Çalışanların davranışları } \\
\text { - } & \text { Menü çeşitliliği } \\
\text { - } & \text { Dekorun etnik restorana uyumu } \\
\text { - } & \text { Çocuklar için olanaklar } \\
\text { - } & \text { Açıllş saati }\end{array}$ & & \\
\hline $\begin{array}{c}\text { Çin } \\
\text { Restoranları }\end{array}$ & $\begin{array}{ll}\text { - } & \text { Yiyecek kalitesi } \\
\text { - } & \text { Servis kalitesi } \\
\text { - } & \text { Hijyen } \\
\text { - } & \text { Temizlik } \\
\text { - } & \text { Çevre kalitesi } \\
\text { - } & \text { Fiyat } \\
\end{array}$ & $\begin{array}{c}\text { Kebap } \\
\text { Restoranları }\end{array}$ & $\begin{array}{ll}\text { - } & \text { Hizmet } \\
\text { - } & \text { Atmosfer } \\
\text { - } & \text { Yiyecekler } \\
\text { - } & \text { Kolaylıklar }\end{array}$ \\
\hline
\end{tabular}

Tablo 3- Restoran Seçim Ölçütlerinin Tüketicilerin Demografik Özelliklerine Göre Bölümlendirilmesi

\begin{tabular}{|c|c|}
\hline $\begin{array}{c}\text { Tüketicilerin Demografik } \\
\text { Özellikleri }\end{array}$ & Seçim Ölçütleri \\
\hline Çocuklu Aileler & $\begin{array}{ll}\text { - } & \text { Sağlık } \\
\text { - } & \text { Hijyen } \\
\text { - } & \text { Güvenilirlik } \\
\text { - } & \text { Rahatlık } \\
\text { - } & \text { Çocukların zaman geçirebilecekleri alanın olması }\end{array}$ \\
\hline Öğrenciler & $\begin{array}{ll}\text { - } & \text { Hizmet kalitesi } \\
\text { - } & \text { Uygun fiyat } \\
\text { - } & \text { Temizlik }\end{array}$ \\
\hline Turistler & $\begin{array}{ll}\text { - } & \text { Personel kalitesi } \\
\text { - } & \text { Yiyecek ve içeceğin tazeliği } \\
\text { - } & \text { Restoranın 1sısı } \\
\text { - } & \text { Temizlik } \\
\text { - } & \text { Menünün anlaşılırlığ1 } \\
\text { - } & \text { Internet hizmeti } \\
\text { - } & \text { Engelli hizmeti }\end{array}$ \\
\hline 50 yaş üstü bireyler & $\begin{array}{ll} & \text { (Lüks restoranlar) } \\
\text { - } & \text { Yiyecek ve içeceğin lezzeti } \\
\text { - } & \text { Yiyecek ve içeceğin kalitesi } \\
\text { - } & \text { Hizmet kolaylığ1 } \\
\text { - } & \text { (Aç1k büfe) } \\
\text { - } & \text { Yiyenü çeşitliliği } \\
\text { - } & \text { Otopark ve içeceğin lezzeti } \\
\text { - } & \text { Yiyecek ve içeceğin kalitesi } \\
\text { - } & \text { (Gündelik restoranlar) } \\
\text { - } & \text { Yiyecek ve içeceğin lezzeti } \\
\text { - } & \text { Hiz̧ececeğin kolaylığ kalitesi } \\
\end{array}$ \\
\hline Farklı bireylere göre & $\begin{array}{ll}\text { - } & \text { Alkol servisi } \\
\text { - } & \text { Çocuklara yönelik hizmet } \\
\text { - } & \text { Kredi kartıyla ödeme imkânı } \\
\text { - } & \text { Otopark bulunması } \\
\text { - } & \text { Servis edilen mutfak türü } \\
\text { - } & \text { Teras } \\
\text { - } & \text { Sakinlik }\end{array}$ \\
\hline
\end{tabular}

Tablo 2'de, incelenen çalışmalarda ortaya konulan restoran seçim ölçütleri, restoranın temasına göre kategorize edilmiştir. Tablo, restoran türlerine göre tüketicilerin en çok hangi kriterlere önem verdiğini ortaya koymaktadır. Teması belirtilmeyen standart restoranlarda daha 
fazla kriterin belirtildiği görülmektedir. Kriterler incelendiğinde, restoranın temasına göre farklılıklar meydana geldiği gibi belirtilen çoğu kriterin de benzer olduğu sonucuna ulaşılmaktadır. Tablo 3'te ise, farkl1 demografik özelliklere sahip tüketicilerin, restoran seçerken dikkat ettikleri unsurlar verilmiştir. İncelenen çalışmalarda, çocuklu aileler, turistler, öğrenciler, 50 yaş üstü bireyler ve özellik belirtilmeden farklı bireyler ele alınmasından dolayı, tabloda bu kategorilere yer verilmiştir. Tablo incelendiğinde, farklı tüketici kesimlerinin, bir restoranı tercih ederken farklı unsurlara önem verebildiği görülmektedir.

\section{SONUÇ}

Restoran seçim ölçütleri, tüketiciler için karar verme sürecinde önemli bir unsurdur. Tüketiciler bir restoranı seçerken, bazı faktörlerden etkilenmekte ve belirledikleri kriterlere göre bir restoranı seçmektedir. Restoran seçimi, çok kriterli karar verme sistemidir. Kültürler ve alt kültürler arasında (kıtalar, bölgeler, ülkeler ve ülke içerisinde bulunan alt kültürler), tüketici tercihleri, restoran seçim kriterleri ve müşteri memnuniyeti açısından önemli farklılıklar bulunmaktadır. Ayrıca, restoranın türü (lüks, geleneksel, fast food), restoranın özellikleri (konum, dış ve iç tasarım, personel) ve tüketicilerin demografik özellikleri arasında da farklılıklar bulunmaktadır. Bunların güçlü özellikler olmasından dolayı, restoran seçim kriterlerinin sürekli olarak araştırılması gerekmektedir (Lehota, Könyves ve Dunay, 2015: 24). Dolayısıyla bu çalışmanın amacı, tüketicilerin restoran seçim ölçütleri üzerine yapılan çalışmalarda ortaya konan kriterleri bir çalışma altında incelemektir. Bu sayede, farklı çalışmalarda ortaya konan farklı ve benzer ölçütler kategorize edilebilecektir.

Çalışmada, literatür taramasına dayalı bibliyografik yöntem kullanılmıştır. Bu kapsamda, tüketicilerin restoran seçim ölçütlerinin belirlendiği çalışmalar incelenmiştir. İncelenen çalışmalar, 26 makale, 3 tez ve 1 bildiri olmak üzere toplam 30 araştırmadır. Kapsama alınan araştırmaların 17'si ulusal, 13'ü yabancı çalışmalardır. Konu ile ilgili kapsama alınan çalışmalar, 2002-2020 yılları arasında gerçekleştirilen çalışmalardır. Ayrıca, konunun son yıllarda araştırmacılar açısından önem gördüğü ve üzerinde çok çalışıldığ1 saptanmıştır. Çalışmalar incelendiğinde, tüketicilerin restoran seçerken kriter olarak; yiyeceğin türü, yiyeceğin kalitesi, lezzet, fiyat, servis kalitesi, personelin tutumu, atmosfer, dekor, kolaylıklar, konum, otopark, çocukların rahat edebilecekleri alan gibi birçok faktör belirledikleri görülmüştür. Aynı zamanda, tüketicilerin restoran tercihi yaparken dikkate aldığ 1 faktörlerin, tüketicilerin yaşına, cinsiyetine, medeni durumuna, eğitim düzeyine, gelirine ve mesleğine göre farklılık gösterdiği saptanmıştır. Restoran seçim ölçütlerinin bireylerin demografik özelliklerine göre değiştiğini belirten birçok çalışma yapılmıştır (Tayfun ve Tokmak, 2007; Harrington ve diğerleri, 2011; Yüksekbilgili, 2014; Canoğlu ve Ballı, 2018; Araz, 2019; Aş1k, 2019; Emir ve Özdemir, 2019; Kurnaz ve Şengül, 2019; Türkay ve Atasoy, 2020). Bununla birlikte, restoranın türüne göre de belirlenen kriterlerin farklılık gösterdiği saptanmıştır.

Sonuç olarak, restoran işletmeleri tüketicilerin sadece yemek yeme ihtiyaçlarını karşıladığı mekanlar değildir. Aynı zamanda sosyalleşme, rahatlama, farklı atmosferlerde bulunma, farklı lezzetleri tatma gibi ihtiyaçlarını da karşılamaktadır. Bu açıdan değerlendirildiğinde, tüketicilerin restoran seçim kriterleri karmaşık bir yapıda olabilmektedir. Restoran işletmecileri potansiyel müşterileri kendi bünyelerine çekebilmek için bu çalışmada kategorize edilen kriterleri dikkate almalıdırlar. Bu sayede daha fazla tercih edilebilir işletme konumuna gelebilmeleri mümkündür.

\section{Kaynakça}

Akbar, Y. A. A. ve Alaudeen, M. S. S. (2012). Determinant of Factors That Influence Consumer in Choosing Normal Full-Service Restaurant: Case in Seri Iskandar, Perak. South East Asian Journal of Contemporary Business, Economics and Law, 1, 137- 145.

Akgündüz, Y., Akdağ, G. ve Metin, U. (2019). Restoran Seçimi Kriterlerinin Müşteri Sadakatine Etkisi: Mersin'de Bir Araştırma. Anadolu Üniversitesi Sosyal Bilimler Dergisi, 19(4), 1-14. https://doi.org/10.18037/ausbd.668597 
Albayrak, A. (2014). Müşterilerin Restoran Seçimlerini Etkileyen Faktörler: İstanbul Örneği. Anatolia: Turizm Araştırmaları Dergisi, 25(2), 190-201. DOI: 10.17123/atad.vol25iss255949

Alonso, A. B., O'neill, M., Liu, Y. ve O'shea, M. (2013). Factors Driving Consumer Restaurant Choice: An Exploratory Study From the Southeastern United States. Journal of Hospitality Marketing \& Management, 22(5), 547-567. https://doi.org/10.1080/19368623.2012.671562

Araz, U. (2019). Kapadokya Bölgesine Gelen Turistlerin Restoran Seçim Ölçütleri Üzerine Bir Araştırma (Basılmamış Yüksek Lisans Tezi). Nevşehir: Nevşehir Hacı Bektaş Veli Üniversitesi.

Arıker, Ç. (2012). Tüketicilerin Restoran Seçiminde Kullandıkları Seçim Kriterleri ile Demografik Özellikleri Arasındaki İlişki. Öneri Dergisi, 10(38), 11-31.

Aşık, N. A. (2019). Çocuklu Ailelerin Restoran Seçimlerini Etkileyen Faktörler: İzmir'de Bir Araştırma. Güncel Turizm Araştırmalan Dergisi, 3(1), 150-168. DOI: 10.32572/guntad.512583

Auty, S. (1992). Consumer Choice and Segmentation in the Restaurant Industry. The Services Industries Journal, 12(3), 324-339. https:// doi.org/10.1080/02642069200000042

Badem, E. ve Öztel, A. (2018). Restoran Seçiminde Tüketiciyi Etkileyen Faktörlerin DEMATEL Yöntemiyle Değerlendirilmesi: Bir Uygulama. Yönetim, Ekonomi, Edebiyat, İslami ve Politik Bilimler Dergisi, 3(1), 7089. DOI: $10.24013 /$ jomelips.429389

Batra, A. (2008). Foreign Tourists' Motivation and Information Source(s) Influencing Their Preference for Eating Out at Ethnic Retaurants in Bangkok. International Journal of Hospitality \& Tourism Administration, 9(1), 1-17. https://doi.org/10.1080/15256480801910178

Bettman, J. R., Johnson, E. J. ve Payne, J. W. (1991). Consumer Decision Making. In M. Asameniw (Ed.)., Handbook of Consumer içinde (s. 50-79). California: BerkeleyHaas.

Canoğlu, M. ve Ballı, E. (2018). Tüketicilerin Kebap Restoranı Tercihlerini Etkileyen Faktörler- Adana Örneği. Organizasyon ve Yönetim Bilimleri Dergisi, 10(1), 30-43.

Cevizkaya, G. (2015). Tüketicilerin Etnik Restoran İşletmelerini Tercih Nedenleri: İstanbul'da Bir Araştırma (Basılmamış Yüksek Lisans Tezi). Balıkesir: Balıkesir Üniversitesi.

Choi, J. ve Zhao, J. (2010). Factors Influencing Restaurant Selection in South Florida: Is Healt Issue One of the Factors Influencing Consumers' Behavior When Selecting a Restaurant? Journal of Foodservice Business Research, 13(3), 237-251. https://doi.org/10.1080/15378020.2010.500254

Chua, B., Karim, S., Lee, S. ve Han, H. (2020). Customer Restaurant Choice: An Empirical Analysis of Restaurant Types and Eating- Out Occasions. International Journal of Environmental Research and Public Health, 17(17), 1-23. https://doi.org/10.3390/ijerph17176276

Clemes, M. D., Gan, C. ve Sriwongrat, C. (2013). Consumer's Choice Factors of an Upscale Ethnic Restaurant. Journal of Food Products Marketing, 19(5), 413-438. https:/ / doi.org/10.1080/10454446.2013.724364

Cullen, F. (2005). Factors Influencing Restaurant Selection in Dublin. Journal of Foodservice Business Research, 7(2), 53-85. https://doi.org/10.1300/J369v07n02_05

Cömert, M. ve Özata, E. (2016). Tüketicilerin Yöresel Restoranları Tercih Etme Nedenleri ve Karadeniz Mutfağ1 Örneği. Uluslararası Sosyal Araştırmalar Dergisi, 9(42), 1963-1974. DOI: 10.17719/jisr.20164216304

Çakıcı, A.C. ve Yıldız, E. (2018). Müşterilerin Restoran Tercihine Göre Kümelendirilmesi Üzerine Kayseri' de Bir Araştırma. Türk Turizm Araştırmaları Dergisi, 2(3), 10-20.

Doğan, S., Şanlıer, N. ve Tuncer, M. (2010). Yiyecek İçecek İşletmelerinin Satış Çabalarında Etik: Kastamonu İli Örneği. Kastamonu Ĕ̆itim Dergisi, 18(1), 241-256.

Emir, O. ve Özdemir, N. (2019). A Study to Determine the Effect of Turkish Customers' Cultural Values on Restaurant Preferences. Journal of Tourism and Gastronomy Studies, 7(4), 2894-2906. DOI: 10.21325/jotags.2019.506

Eroğlu, E. (2012). Tüketici Davranışı Kavramı ve Özellikleri. Y. Odabaşı (Ed.)., Tüketici Davranışları içinde (s. 223). Eskişehir: Anadolu Üniversitesi Yayını. 
Fidan, H., Teneva, A., Stankov, S. ve Dimitrova, E. (2018). Consumer's Behavior of Restaurant Selection. 2018 International Conference on High Technology for Sustainable Development (HiTec), 11-14 Haziran 2018, Sofya, Bulgaristan.

Harrington, R. J., Ottenbacher, M.C. ve Kendall, KW (2011). Fine-Dining Restaurant Selection: Direct and Moderating Effects of Customer Attributes. Journal of Foodservice Business Research, 14(3), 272-289. https://doi.org/10.1080/15378020.2011.594388

Heung, V. C. S. (2002). American Theme Restaurants: A Study of Consumer's Perceptions of the Important Attributes in Restaurant Selection. Asia Pasific Journal of Tourism Research, 7(1), 19-28. https://doi.org/10.1080/10941660208722106

Hyun, S. S. (2010). Predictors of Relationship Quality and Loyalty in the Chain Restaurant Industry. Cornell Hospitality Quarterly, 51(2), 251-267. DOI: 10.1177/1938965510363264

Jung, J. M., Sydnor, S., Lee, S. K. ve Almanza, B. (2015). A Conflict of Choice: How Consumers Choose Where to Go for Dinner. International Journal of Hospitality Management, 45, 88-98. https://doi.org/10.1016/j.ijhm.2014.11.007

Karakaş, Y. E., Çiçek, B.ve İştin, A. E. (2015). Yerel ve Uluslararası Markalı Yiyecek \& İçecek İşletmelerinin Tercih Edilme Nedenlerini Belirlemeye Yönelik Bir Araştırma. 16. Ulusal Turizm Kongreler Kitabı, 12-15 Kasım 2015, Çanakkale.

Kılınç, O. (2011). Restoran İşletmelerinde Hizmet Garantisi Uygulamaları ve Müşteri Tercihlerine Etkileri (Basılmamış Doktora Tezi). Aydın: Adnan Menderes Üniversitesi.

Kim, S. ve Chung, J. (2011). Restaurant Selection Criteria: Understanding the Roles of Restaurant Type and Customers' Sociodemographic Characteristics. 16. Graduate Student Research Conference in Hospitality and Tourism, 6-8 Ocak 2011, Teksas.

Kim, Y., Raab, C. ve Bergman, C. (2010). Restaurant Selection Preferences of Mature Tourists in Las Vegas: A Pilot Study. International Journal of Hospitality $\mathcal{E}$ Tourism Administration, 11(2), 157-170. https://doi.org/10.1080/15256481003732816

Kurnaz, A. ve Şengül, S. (2019). Marmaris'i Ziyaret Eden Yerli Turistlerin Kişisel Özellikleri ile Etnik Restoranları Seçim Kriterleri Arasındaki İlişkilerin Belirlenmesi. Journal of Recreation and Tourism Research, 6(3), 306-316. DOI: 10.31771/jrtr.2019.33

Lawson, R. (1997). Consumer Decision Making within a Goal- Driven Framework. Psychology \& Marketing, 14(5), 427-449. https://doi.org/10.1002/(SICI)1520-6793(199708)14:5<427::AID-MAR1>3.0.CO;2-A

Lehota, J., Könyves, E. ve Dunay, A. (2015). Key Factors of a Successful Restaurant Strategy in Hungary. Business, 22-27. DOI: 10.17626/dBEM.ICoM.P00.2015.p005

Mhlanga, O. ve Tichaawa, T. M. (2016). What are the Current Factors Affecting Consumer Selection Criteria in Formal Full Service Restaurants in Port Elizabeth, South Africa. African Journal of Hospitality, Tourism and Leisure, 5(2), 1-11.

Njite, D., Dunn, G. ve Kim, L. H. (2008). Beyond Good Food What Outher Attributes Influence Consumer Preference and Selection of Fine Dining Restaurants? Journal of Foodservice Business Research, 11(2), 237266. https://doi.org/10.1080/15378020801995523

Oğuzalp, A. (2020). Üniversite Öğrencilerinin Restoran Tercihini Etkileyen Faktörler: Konya Örneği (Basılmamı̧̧ Yüksek Lisans Tezi). Konya: KTO Karatay Üniversitesi.

Özdemir, B. (2010). Dışarıda Yemek Yeme Olgusu: Kuramsal Bir Model Önerisi. Anatolia: Turizm Araştırmalan Dergisi, 21(2), 218-232.

Parsa, H.G., Self, J. T., Njite, D. ve King, T. (2005). Why Restaurants Fail? Cornell Hotel and Restaurant Administration Quarterly, 46(3), 304-322. https://doi.org/10.1177/0010880405275598

Sudhagar, D. P. ve Rajendran, G. (2017). Selection Criteria of Customers of Chinese Restaurants and Their Dining Habits. International Journal of Knowledge Management in Tourism and Hospitality, 1(1), 57-75. https://doi.org/10.1504/IJKMTH.2017.084587 
Taşdağıtıcı, E. ve Güçer, E. (2016). Yiyecek İçecek İşletmelerinin Sınıflandırma Sistemleri: İşletmelerin Algısına Yönelik Bir Araştırma. 3rd International Congress of Tourism \& Management Researches, 20-22 Mayıs 2016, Antalya, Türkiye.

Tayfun, A. ve Tokmak, C. (2007). Tüketicilerin Türk Usulü Fast Food İşletmelerini Tercih Etme Sebepleri Üzerine Bir Araştırma. Elektronik Sosyal Bilimler Dergisi, 6(22), 169-183.

Tuna, A. (2017). Müzik Bibliyografyası Bağlamında 2000-2017 Yılları Arasında Yapılmış Lisansüstü Tezler ve Yöntemleri. EÜ Devlet Türk Musikisi Konservatuvarn Dergisi, 11, 125-133.

Türkay, O. ve Atasoy, B. (2020). Restoran Seçiminde Kişiliğin Rolü: Sakarya Örneği. Selçuk Üniversitesi Sosyal Bilimler Meslek Yüksekokulu Dergisi, 23(2), 401-412. https:/ / doi.org/10.29249/selcuksbmyd.687053

Wibowo, S. W. ve Tielung, M. (2016). Analytical Hierarchy Process (AHP) Approach on Consumer Preference in Franchise Fast Food Restaurant Selection in Manado City (Study at: McDonald's, KFC and A\&W). Jurnal EMBA: Jurnal Rıset Ekonomi, Manajemen, Bisnis Dan Akuntansi, 4(2), 22-28.

Yüksekbilgili, Z. (2014). Restoran Seçim Ölçütleri Üzerine Bir Araştırma. Journal of Yasar University, 9(36), 63536360. 